\title{
PEREBUTAN MODALITAS SOSIAL DAN MODEL INTEGRASI DESA BERLEGITIMASI RELIGIUS PADA MASYARAKAT PANTAI UTARA DI PROVINSI BALI
}

\author{
I Wayan Artanayasa \\ Jurusan Penjaskesrek, Fakultas Olahraga dan Kesehatan \\ Universtitas Pendidikan Ganesha \\ Singaraja, Indonesia
}

e-mail: iwayan.artanayasa@yahoo.com

\begin{abstract}
Abstrak
Target utama dari penelitian ini adalah untuk mengidentifikasi dan memetakan dinamika konflik yang terjadi dalam masyarakat tradisional kawasan pantai utara Bali, sebagai potret salah satu masyarakat Bali Kuno berkaitan dengan adanya upaya terprogram untuk memodernisasi agama demi kepentingan industri kepariwisataan berdasarkan tingkat dan jenis konflik yang terjadi di tengah-tengah masyarakat desa adat, serta mengembangkan model penanganan konflik berbasis kearifan nilai-nilai lokal masyarakat desa adat. Penelitian ini menggunakan pendekatan penelitian dan pengembangan (Research \& Development). Model pengembangan yang digunakan mengacu pada model pengembangan dari Plomp (1997). Prosedur pengembangan model, meliputi fase-fase: (1) analisis kebutuhan, (2) pengembangan model, (3) integrasi model, (4) validasi preliminary model, (5) penerapan model. Pada penelitian ini, analisis data dilakukan secara deskriptip-kualitatif.

Hasil penelitian menunjukkan bahwa: (1) masyarakat desa adat Bali Utara memandang bahwa konflik adat yang terjadi merupakan imbas dari "ketidaknyamanan" sekelompok orang dalam mengelola diri dan lingkungannya. (2) konflik adat yang terjadi pada desa adat Bali Utarasebagai dampak dari pengembangan industri pariwisata dan diperkuat lagi oleh sengketa masalah konservasi dan kepemilikan tanah adat terpola menjadi dua, yaitu konflik yang bersifat horizontal dan konflik yang bersifat vertikal. (3) pengembangan industri pariwisata di desa adat Bali Utara telah membawa dampak yang sangat tajam pada aspek sosial-ekonomi masyarakat. (4) sistim dan bentuk tata pemerintahan desa adat diantara desa adat Bali Utaramemiliki persamaan yang sangat banyak, karena kedua desa tersebut tergolong ke dalam desa adat kuno yang merupakan desa yang dibangun oleh para pelarian Majapahit gelombang pertama. (5) faktor dominan yang memicu timbulnya konflik adat di kalangan masyarakat desa Bali Utara, yaitu: pengembangan desa adat sebagai kawasan wisata budaya, sistim konservasi dan kepemilikan tanah adat sebagai pendukung industri pariwisata, "upaya penjualan" simbol-simbol keagamaan dan budaya masyarakat bagi kepentingan pengembangan industri pariwisata, dan kebijakan pemerintah desa adat dan pemerintah daerah setempat.
\end{abstract}

Kata kunci: model integrasi desa adat, legitimasi religius, konflik, modalitas sosial 


\begin{abstract}
The main target of this study is to identify and map the dynamics of conflict in traditional societies the northern coast of Bali, as a portrait of one of the ancient Balinese related to the programmatic efforts to modernize the religion for the sake of tourism industry based on the level and types of conflicts that occur in the middle center of the traditional village communities, and to develop a model of conflict resolution wisdom-based values of local indigenous villagers. This study uses the approach of research and development (Research \& Development). Model development used refers to the model development of Plomp (1997). Model development procedures, including phases: (1) needs analysis, (2) development model, (3) integration model, (4) preliminary validation of the model, (5) the application of the model. In this study, data analysis conducted descriptivequalitative.

The results showed that: (1) North Balinese villagers saw that the traditional conflict that occurs is the impact of the "inconvenience" a group of people to manage themselves and their environment. (2) conflict that occurs in traditional Balinese village Utara the impact of the development of the tourism industry and reinforced by the disputed issues of conservation and customary land ownership pattern into two, the conflicts that are horizontal and vertical conflicts. (3) development of the tourism industry in North Balinese village has brought a sharp impact on the socioeconomic aspects of society. (4) the system and form of governance among rural indigenous Balinese village Utara equation very much, because the two villages belonging to the ancient indigenous villages are villages built by the first wave of escapees Majapahit. (5) the dominant factors that lead to conflict among the peoples of North Balinese village, namely: the development of the traditional village as an area of cultural tourism, conservation and the system of customary land tenure as a supporter of the tourism industry, "sales effort" symbols of religious and cultural life of the the interests of the development of the tourism industry, and government policies and traditional village local government.
\end{abstract}

Keywords: integration model village customs, religious legitimacy, conflict, social modalities

\section{PENDAHULUAN}

Bagi masyarakat Bali, Agama Hindu merupakan simbol sakralisasi yang telah bertahan ratusan bahkan mungkin ribuan tahun, memiliki peran dan fungsi yang sangat strategis dalam setiap langkah masyarakat pendukungnya (Atmadja, 2006). Hal ini bisa dilihat dari eksistensi politis dan sosiologis yang dilakukan oleh desa adat yang ada di kalangan masyarakat Bali dalam memperkuat legitimasi sosialnya di tengah-tengah masyarakat pendukungnya. Realitas yang saat ini tampak berkembang di sebagian masyarakat hindu Bali, khususnya masyarakat tradisional Bali Age (Bali Asli yang telah ada sebelum kedatangan pengungsi Majapahit) adalah adanya upaya mengidustrikan Agama Hindu, khususnya di kalangan pelaku kepariwisataan. Bentuk dari upaya itu antara lain, pementasan tari-tarian keagamaan yang bersifat sakral sebagai 
jamuan para wisatawan, eksploitasi tempat-tempat pemujaan keagamaan yang dikeramatkan oleh masyarakat Hindu Bali untuk kepentingan industri pariwisata, dan penyederhanaan ritualritual keagamaan dengan alasan efesiensi dan efektivitas, untuk mendongkrak animo pariwisata budaya. Dampak dari sinyalemen tersebut adalah munculnya konflik-konflik adat yang distimuli oleh masalah penafsiran terhadap nilai-nilai agama Hindu, yang saat ini mulai "dijual" untuk membangkitkan gerak nafas industri kepariwisataan.

Berdasarkan latar belakang dan fokus masalah di atas, maka tujuan pokok dari penelitian ini adalah: "memetakan konflik dan mengembangkan model integrasi desa adat dalam penanganan konflik-konflik horizontal yang terjadi pada masyarakat Bali age yang berada di kawasan pantai utara pulau bali. Secara khusus, tujuan dari penelitian ini dapat dijabarkan sebagai berikut: (1) Menggali dan memformulasikan faktor-faktor yang menjadi pemicu timbulnya konflik di kalangan masyarakat tradisional Bali Age di kawasan pantai utara pulau Bali, dan memformulasikan pandangan dan sikap masyarakat tradisional Bali Age terhadap konflik yang terjadi di wilayah desanya, serta mengidentifikasi kelompok-kelompok masyarakat yang berkonflik. (2) Menggali dan memetakan dampak sosial-politik yang terjadi terkait dengan terjadinya konflik di kalangan masyarakat tradisional Bali Age terhadap keutuhan desa adat ?, dan bagaimana pula dampak konflik tersebut terhadap kehidupan sosial-budaya masyarakat setempat. (3) Memetakan bentuk dan intensitas konflik yang terjadi dikalangan masyarakat tradisional Bali Age pantai utara Bali, dan menganalisis dinamika konflik yang muncul dilihat dari perspektif keutuhan etnisitas Bali Age sebaga komunitas minoritas di Provinsi Bali. (4) Mengembangkan model integrasi desa adat dalam penanganan konflik sosial yang berlegitimasi religius, sebagai dampak dari perebutan modalitas sosial pada masyarakat bali age di kawasan pantai utara pulau Bali. (5) Merumuskan rekayasa sosial penanganan konflik yang dipicu oleh perebutan modalitas sosial pada masyarakat bali age di pantai utara Provinsi Bali.

Secara etimologis, konflik adalah "hubungan antara dua pihak atau lebih (individu atau kelompok) yang memiliki atau merasa memiliki sasaran-sasaran yang tidak sejalan" (Fisher et al., 2001: 4). Sumber konflik bisa melekat pada tataran struktur maupun kultur yang berlaku dalam masyarakat maupun kelompok sosial yang berkonflik. Gejala ini terungkap pada berbagai studi tentang konflik pada masyarakat Bali. Bahkan, berdasarkan studi yang ada, bisa pula diketahui bahwa konflik bukan masalah baru pada masyarakat Bali, melainkan sudah berlangsung sejak lama.

Studi tentang konflik pada masyarakat Bali yang sekaligus memperlihatkan sumber masalah yang menyebabkan timbulnya konflik bisa dilihat, misalnya, dari kajian Atmadja (2001), yang membahas konflik yang terjadi di Buleleng pada tahun 1925, yakni antara kaum Jaba melawan kaum Triwangsa (Brahmana, Ksatria, dan Wesya). Sumber konflik pada konteks ini adalah keinginan kaum Jaba untuk melakukan perubahan sosial yang 
berdimensi kultural maupun struktural sehingga melahirkan suatu tatanan masyarakat Bali yang bercorak egaliter. Hal ini tidak bisa dilepaskan dari pandangan kaum Jaba bahwa ada kendala kultural maupun struktural yang menyebabkan mereka tersubordinasi oleh kaum Tri Wangsa sehingga memerlukan perombakan agar tercipta masyarakat yang egaliter. Gagasan ini ditentang oleh kaum Tri Wangsa sehingga konflik antarkasta menjadi tidak terhindarkan. Akar identitas dalam masyarakat terletak dalam banyak aspek seperti perbedaan etnik, ras, agama, dan jender. Namun bentuk yang tertua dan banyak diikaji adalah dari sudut ras dan etnik, sedangkan bentuk yang lain mengikuti perkembangan ras dan etnik. Misalnya, agama pada umumnya dan awalnya berasal dan paralel dengan perkembangan etnik, demikian juga identitas jender berkembang dalam konteks etnik dan agama dan begitu seterusnya. Ada dua istilah yang kerap digunakan ketika orang berbicara tentang perkembangan identitas kelompok : ras dan etnisitas. Keduanya saling berkaitan tetapi memiliki perbedaan makna.

Di sisi lain etnisitas merujuk kepada pengelompokan orang berdasarkan warisan sosial budaya. Kesamaan orang dalam satu kelompok etnik ditandai dengan kesamaan bahasa, adat istiadat, budaya, dan juga agama yang pada akhirnya kesamaankesamaan itu membentuk identitas sosial. Ada ahli yang sedikit berbeda menyatakan pendapatnya bahwa etnisitas merujuk kepada perasaan bersama " a sense of peoplehood", merasa menjadi bagian dari suatu kelompok yang anggotanya memiliki kesamaan, namun di dalamnya terkandung pula aspek-aspek biologis dan budaya (Mendoza \& Napoli, 1990: 96). Pandangan yang melihat perkembangan etnisitas sebagai unsur budaya dan biologis, melahirkan dua perspektif tentang etnisitas (Yoon, 1988). Pertama melihat etnisitas dalam perspektif "ascribed or primordial ties", dan lainnya sebagai "social consruction". Perspektif Ascribed or primordial ties melihat etnisitas sebagai atribut yang given dan tidak dapat dirubah (termasuk unsur biologis), sedangkan social construction melihat etnisitas terjadi sebagai suatu konstruk yang yang terjadi dalam kehidupan bermasyarakat karena adanya kepentingan bersama, kesamaan budaya, serta kegiatan bersama. Selain persoalan yang berasal dari dalam masyarakat (identity development), sebagai tantangan bagi terbentuknya masyarakat multikutural, juga ada tantangan dari luar masyarakat tersebut. Masyarakat multikultural yang demokratis memiliki dua dimensi yakni internal, dan eksternal. Berikut ini tinjauan teoritis tantangan luar yang perlu mendapat perhatian dalam membangun masyarakat multikultural.

Konflik merupakan keadaan yang tidak terpisahkan dari keberadaan masyarakat majemuk. Konflik merupakan sinyal bahwa ada sesuatu yang salah dalam masyarakat sehingga dapat dijadikan generator perubahan menuju masyarakat multikultural yang lebih demokratis. Untuk itu, perlu dikenali karakteristik konflik sehingga dapat dicarikan upaya mengelolanya. Varshney (2002: 21) mengemukakan ada empat tradisi pendekatan untuk

Jurnal IImu Sosial dan Humaniora | 363 
memahami konflik dalam masyarakat majemuk yang dibagi ke dalam dua kelompok. Yang pertama adalah esensialisme dan instrumentalisme, dan yang kedua adalah kostruktivisme dan postmodernisme.

Dalam

pandangan esensialisme konflik yang terjadi dilihat dari dua argumen yaitu, primodial dan warisan kemanusian. Konflik diterjemahkan sebagai konsekwensi dari keterikatan karena pertalian darah dan kesamaan keturunan. Sedangkan, dalam pandangan istrumentalis, etnisitas tetap menjadi poin utama dalam konflik. Namun hal tersebut, bukan disebabkan kekuatan ikatannya tetapi karena dimobilisasi untuk tujuan tertentu. Para elit melihat potensi ikatan yang kuat dalam etnik (kelompok) sebagai cara memobilisasi massa untuk mencapai tujuan mereka.

Model integrasi desa adat dan elaborasi nilai-nilai lokal masyarakat setempat dalam penyelesaian konflik sosial-ekonomi yang dikembangkan dalam penelitian ini, setelah dilakukan verifikasi dan uji pakar, sepenuhnya akan diberikan kepada pemerintah daerah kabupaten dan pelaku industri pariwisata untuk penerapannya secara luas, dengan tetap melibatkan desa adat sebagai "penguasa wilayah", sehingga penggunaan model ini benar-benar sesuai dengan kondisi riil, serta mengkombinasikan berbagai potensi dan modalitas masing-maising fihak yang terlibat konflik. Disisi lain, pelaksanaan model tersebut akan didampingi oleh tim peneliti melalui mekanisme pendampingan secara institusional, yaitu pelibatan lembaga perguruan tinggi tim peneliti, yang terpola dalam bentuk kerjasama institusi antara pemerintah daerah kabupaten Buleleng dan kabupaten Karangasem dengan Undiksha, sebagai lembaga pendidikan tinggi. Pengembangan model integrasi desa adat dalam konteks penanganan konflik sosial berlatar unsur religius dan sara di kalangan masyarakat pantai utara pulau bali ini, benar-benar memiliki nilai strategis dan fungsional, khususnya dalam rangka menekan meluasnya daerah konflik dan pemaknaan terhadap ekses yang mungkin ditimbulkan oleh konflik tersebut.

\section{METODE PENELITIAN}

Penelitian ini menggunakan desain penelitian pengembangan yang dipadukan dengan metode penelitian budaya untuk mengidentifikasi, menganalisis, mengkomparasikan, mensinergikan, mengembangkan, mengevaluasi, dan mendesiminasikan model yang dihasilkan, sehingga mampu mengurai masalah-masalah penelitian secara mendasar (grounded). Model yang diacu dalam pengembangan model integrasi desa adat berbasis kearifan nilai-nilai lokal dan legalitas spiritual ini adalah model penelitian pengembangan model Stanford (1998) dan model penelitian budaya menurut Nickerson (1971), yang secara umum terdiri dari: (1) fase analisis masalah, (2) fase integrasi nilai, (3) fase pengembangan model, (4) fase pengujuan model, dan (5) fase evaluasi dan desiminasi model.

Instrumen yang akan digunakan dalam penelitian ini terdiri dari: (1) pedoman observasi, (2) pedoman wawancara, (3) pedoman studi dokumen, (4) kuisioner, (5) social appraisal context, dan (6) penilaian 
kinerja model. Terkait dengan instrumen penelitian tersebut, maka metode penjaringan data yang akan dikembangkan dalam penelitian ini terdiri dari: (1) observasi partisipatif, (2) wawancara klinis, (3) penyebaran kuisioner, (4) interrater validity respons, (5) focus groups discussion, (6) expert judgement, dan (7) pengujian lapangan. Keseluruhan data dalam penelitian ini akan dianalisis dengan menggunakan beberapa teknik analisis data, yaitu: (1) untuk data yang bersifat kualitatif, terutama yang berkaitan dengan dinamika proses pengembangan model dan integrasi nilai-nilai lokal masyarakat, datanya akan dianalisis dengan metode deskriptif kualitatif, (2) untuk data pada tahap validasi model, analisis yang dilakukan menggunakan EFA (explanatory factor analisys) dengan menggunakan model SMART (Spesifik, Managable, Applicable, Raliabel, Time Bound) sebagai sub faktor.

\section{HASIL PENELITIAN}

\begin{tabular}{llr}
\multicolumn{2}{c}{ Berdasarkan hasil studi } \\
lapangan terhadap aktivitas dan \\
modalitas sosial serta budaya
\end{tabular} masyarakat desa adat yang berada di kawasan pantai utara pulau bali, serta didukung oleh hasil penyebaran angket kepada responden secara bertujuan, diperoleh data sebagai berikut: (1) tidak semua desa adat yang berada di kawasan pantai utara (pantura) pulau bali memiliki objek pariwisata dan kawasan wisata, (2) secara umum mata pencaharian masyarakat pantura bali adalah nelayan dan petani tambak, (3) terdapat 41 desa adat yang secara geografis keberadaannya di pantura bali, yang tersebar pada 3 kabupaten, yaitu: kabupaten jemberana, kabupaten buleleng, dan kabupaten karangasem. (4) dilihat dari struktur sosial masyarakatnya, tampak bahwa sebagian besar desa adat yang ada di kawasan pantura adalah beragama Hindu, dimana untuk beberapa desa adat di kabupaten jemberana dan buleleng, sebagian kecilnya adalah beragama islam, dan hanya sebagian kecil yang beragama kristen, khususnya yang berada di kawasan kabupaten buleleng. (5) dilihat dari jenjang pendidikan masyarakatnya, sebagian besar masyarakat di kawasan tersebut terutama yang telah berumur di atas 40 tahun adalah tamatan sekolah dasar dan SMP, sementara sebagian kecil saja yang berpendidikan SMA dan sarjana. Sementara untuk penduduk yang berusia produktif (umur 15 - 35 tahun) sebagian besar adalah lulusan SMP dan SMA/SMK.

Mengacu pada hasil studi bibliografi sebagaimana salah satu cara penggalian data dalam penelitian ini, maka dapat dideskripsikan sebagai berikut. Desa adat merupakan suatu lembaga tradisional yang mewadahi kegiatan sosial, budaya dan keagamaan masyarakat umat Hindu di Bali yang telah menjadi tradisi kemasyarakatan secara mantap sebagai warisan dari pada budaya bangsa. Desa adat tidak bisa dipisahkan dengan kehidupan sosial, budaya dan keagamaan masyarakat umat Hindu di Bali karena merupakan satu kesatuan. Desa Adat sebagai Desa dresta adalah kesatuan masyarakat hukum adat di propinsi Bali yang mempunyai satu kesatuan tradisi dan tata krama pergaulan hidup masyarakat umat Hindu secara turun temurun dalam ikatan khayangan tiga yang mempunyai wilayah tertentu dan 
harta kekayaan sendiri. Hal ini menegaskan bahwa desa adat merupakan satu kesatuan masyarakat hukum adat dalam ikatan khayangan tiga yang bersipat otonom, ini berarti desa adat merupakan subyek hukum yang boleh mempunyai hak milik dan berhak mengatur rumah tangganya sendiri.

Desa adat merupakan kesatuan masyarakat dimana rasa kesatuan sebagai warga desa adat terikat oleh wilayah tertentu (karang desa) dengan batasbatas yang jelas dan terikat pula oleh satu sistem tempat persembahyangan yang disebut kahyangan tiga yang terdiri dari Pura Desa, Pura Puseh, Pura Dalem. Masyarakat hukum itu mempunyai hakhak atas tanah, air, tanam-tanaman, bangunan-bangunan, dan benda-benda kramat. Kelompok masyarakat yang merupakan persekutuan hukum mempunyai susunan yang relatif tetap, mempunyai kekuasaan sendiri serta mempunyai kekayaan berupa benda yang kelihatanmaupun tidak kelihatan oleh mata. Masyarakat Bali yang tradisional dan penghidupannya yang bersifat agraris tampak sebagai satu kesatuan yang utuh, kepentingan bersama lebih diutamakan dibandingkan kepentingan kelompok dan individu sebagai warga masyarakat.

Hasil wawancara dan ditunjang oleh observasi partisipatif yang dilakukan oleh tim peneliti diperoleh data bahwa masyarakat (khususnya mereka yang tidak terlibat langsung dalam konflik) di lokasi penelitian terpola ke dalam dua pandangan dan sikap yang sangat kontradiktif, yaitu: (1) kelompok masyarakat yang tidak tahun menahu (tidak ingin tahu) terhadap konflik yang terjadi, dan (2) kelompok masyarakat yang sangat menentang terjadinya konflik dan menyatakan "perang" terhadap mereka yang dipandang sebagai pemicu timbulnya konflik adat di desanya. Fakta ini didukung oleh hasil quisioner yang diberikan kepada masyarakat yang penunjukkannya dilakukan secara random, dimana sebagian besar masyarakat menyatakan tidak ingin terjadi konflik di daerahnya, apalagi yang menyangkut adat istiadat. Mereka berpandangan bahwa konflik adat yang dipicu oleh segelintir orang "hanya" akan menjerumuskan desa mereka kepada situasi yang tidak menguntungkan bagi upaya pembangunan desa dan pelestarian adat istiadatnya.

Perbedaan cara berpikir dan bersikap di kalangan masyarakat, telah memicu timbulnya beberapa konflik berbadau adat yang bersifat horizontal. Konflik yang dimaksud disini, baru pada tataran menruncingnya perbedaan pendapat dan cara menyikapi kebijakan aparat desa yang menjadikan desa mereka sebagai kawasan wisata budaya sebagaimana kebi-jakan pemerintah daerah setempat. Kehadiran kalangan wisatawan manca-negara maupun domestik ke desa mereka oleh sekolompok masyarakat dipandang sebagai "virus berbahaya" bagi keutuhan dan pelestarian adat istiadat desanya, termasuk akan mempengaruhi tinfkat kesakralan benda-benda budaya yang selama ini menjadi simbol transendetal bagi kalangan masyarakat desa setempat.

Kondisi kepariwisataan dan perkembangan industri agrobisnis yang dikembangkan oleh para investor dan pengembang pariwisata, merupakan 
faktor pendukung dan sekaligus penyebab terjadinya pergeseran keberadaan dan fungsi tanah laba pura yang ada di daerah Kintamani. Tanah adat ini, yang dulunya merupakan hak pengelolaannya sepenuh-nya ada di tangan masyarakat secara komunal kemudian beralih ke pada prajuru adat, kini telah beralih kepada kalangan investor kepariwisataan. Peralihan ini dilakukan melalui suatu sangkepan desa adat yang melibatkan seluruh anggota masyarakat desa adat dan instansi pemerintah.

Akhirnya keputusan peralihan hak kelola itu dituangkan dalam suatu surat perjanjian kontrak antara masyarakat desa adat dengan investor. Jangka waktu kontrak ini berkisar antara 20 tahun sampai 30 tahun. Dengan terjadinya peralihan hak kelola ini, maka prajuru adat yang dulunya mendapat "imbalan" atas jabatannya sebagai pelaksana upacara adat yang berupa hak kelola dan hasil dari tanah laba pura, kini diberikan sejumlah hak dan imbalan yang lebih mengacu dan bersifat material.

Adapun hak dan imbalan tersebut berupa pemberian "pemalangan" dalam setiap upacara adat dan pemberian sejumlah uang dalam setiap dilakukan pemungutan peturunan. Besarnya uang tersebut tergantung dari jabatan yang diembannya. Semakin tinggi jabatannya, maka semakin tinggi pula imbalan yang diperolehnya, begitu juga sebaliknya. Peralihan status hak kelola terhadap tanah laba pura menimbulkan pergeseran yang sangat esensial bagi eksistensi dan peran simbolis tanah laba pura. Adapun pergeseran tersebut bermula dari peralihan hak kelola tanah laba pura ke tangan investor. Pada dasarnya masyarakat desa adat (responden) telah menerima apa adanya menyangkut sistim pengelolaan dan konservasi tanah adat yang ada di desa adatnya masing-masing. Mereka meyakini bahwa tanah adat yang mereka miliki merupakan sesuatu yang mengandung nilai magis-religius berdasarkan keyakinannya maisingmasing. Di sisi lain, dasar hukum yang digunakan untuk menetapkan sistim pengelolaan dan konservasi terhadap tanah adat tersebut adalah awig-awig desa adat (hukum adat yang telah disepakati) yang telah mereka susun bersama dan diterima keberlakuannya oleh semua lapisan masyarakat. Sikap masyarakat desa adat terhadap terjadinya sengketa tanah adat yang saat ini marak terjadi di beberapa wilayah desa adat yang ada di Bali, cenderung menolak. Bagi mereka tidak semetinya tanah adat itu disengketakan, mengingat tanah tersebut memiliki nilai simbolis-religius yang sangat tinggi bagi masyarakat setempat.

\section{SIMPULAN}

Berdasarkan hasil penelitian dan pembahasan di atas, dapat dirumuskan simpulan dari keseluruhan proses dan hasil penelitian ini sebagai berikut: (1) Masyarakat desa adat Bali Utara memandang bahwa konflik adat yang terjadi merupakan imbas dari "ketidaknyamanan" sekelompok orang dalam mengelola diri dan lingkungannya. Untuk itu mereka ada yang bersikap menerima konflik sebagai bagian kehidupan yang wajar, dan ada juga yang memandang bahwa konflik tersebut harus sesegera dicarikan jalan keluarnya agar tata kehidupan adat 
istiadat tidak terkontaminasi oleh konflik tersebut. (2) Konflik adat yang terjadi pada desa adat Bali Utarasebagai dampak dari pengembangan industri pariwisata dan diperkuat lagi oleh sengketa masalah konservasi dan kepemilikan tanah adat terpola menjadi dua, yaitu konflik yang bersifat horizontal dan konflik yang bersifat vertikal. Kedua bentuk konflik ini telah membawa dampak terhadap sistim dan tatakrama sosial masyarakat sehari-hari, namun belum mengacu pada terjadinya perpecahan desa adat. (3) Pengembangan industri pariwisata di desa adat Bali Utara telah membawa dampak yang sangat tajam pada aspek sosial-ekonomi masyarakat. Dampak tersebut mengarah pada tumbuhnya diversifikasi mata pencaharian masyarakat dan dinamika sosial masyarakat adat yang semakin kompleks. Hal ini bagi masyarakat desa adat merupakan konsekuesi logis dari sebuah pembangunan. Namun sebagian masyarakat memandang hal tersebut sebagai "dosa para pelaku insutri pariwisata" terhadap tanah leluhurnya sendiri, dan harus segera dihentikan agar tidak merusak tata krama kehidupan masyarakat telah dibangun dan dilestarikan. (4) Sistim dan bentuk tata pemerintahan desa adat diantara desa adat Bali Utaramemiliki persamaan yang sangat banyak, karena kedua desa tersebut tergolong ke dalam desa adat kuno yang merupakan desa yang dibangun oleh para pelarian Majapahit gelombang pertama. Masyarakat desa adat menganut sistim lulu apad dalam penentuan tegak desa dari anggota masyarakatnya. Bagi desa adat, dinamika konflik yang ada di wilayahnya adalah sebuah kewajaran dari sebuah perubahan, sehingga sebagian besar masyarakat justru bersikap tidak mau tahu terhadap konflik adat, karena yang terlibat konflik hanya sebagian kecil dari komunitas masyarakat desa adat di masing-masing desa adat. (5) Bagi kalangan masyarakat pelaku pariwisata, pengembangan industri pariwisata dan implikasi yang ditimbulkannya adalah sesuatu yang tidak mengancam eksistensi desa adat, sepanjang masyarakat tetap pada kontrol diri dan mempertahankan simbol-simbol keagamaan dan adat pada porsi yang wajar. Sementara bagi masyarakat yang tidak bergerak di bidang pariwisata, konflik adat ang terjadi harus ditelaah dari kemurnian nilai-nilai adat dan agama yang selama ini telah mereka gunakan untuk menakar keharmonian hidup masyarakatnya. Bagi masyarakat desa adat, revitalisasi nilai-nilai agama dan adat untuk melakukan kontrol dan menakar baik buruknya pembangunan kepariwisataan adalah sebuah keharusan, untuk meghindarkan desa adat dari ekses negatif pariwisata. Faktor dominan yang memicu timbulnya konflik adat di kalangan masyarakat desa Bali Utara, yaitu: (1) pengembangan desa adat sebagai kawasan wisata budaya, (2) sistim konservasi dan kepemilikan tanah adat sebagai pendukung industri pariwisata, (3) "upaya penjualan" simbol-simbol keagamaan dan budaya masyarakat bagi kepentingan pengembang-an industri pariwisata, dan (4) kebijakan pemerintah desa adat dan pemerintah daerah setempat. Untuk desa adat kawasan karangasem ternyata bentuk dan intensitas konfkiknya jauh lebih tinggi dan dalam dibandingkan dengan 
apa yang terjadi di desa adat kawasan Buleleng. Hal ini disebabkan karena secara geografis desa adat abuan merupakan "daerah perlintasan" wisatawan dari Denpasar menuju Singaraja, sehingga industri pariwisata di desa tersebut jauh lebih maju dibandingkan dengan kawasan Buleleng dan Negara.

\section{DAFTAR PUSTAKA}

Ali, Mursyid (2003) "Konflik Sosial Bernuansa Agama: Studi Kasus Tentang Tragedi Poso", dalam Balitbang Depag RI (ed) Konflik Sosial Bernuansa Agama di Indonesia . Seri II. Departemen Agama RI; Jakarta

Anderson, Benedict (2000) Imagined Community (Komunitas-Komunitas Terbayang). Jakarta: Insist.

Arraiyah, Hamdar (2003) "Peta Kerukunan Umat Beragama di Propinsi Sulawesi Tengah", dalam Balitbang Depag RI (ed) Riuh di Beranda Satu. Peta Kerukunan Umat Beragama di Indonesia. Balitbang Departemen Agama RI: Jakarta

Artanayasa, Wayan (2009). Studi analisis pemanfaatan modalitas social pada pengembangan industry pariwisata dikawasan bali utara (laporan penelitian).

Bloomfield, David cs (2000) "Menganalisis Konflik yang Mengakar", dalam Harris, Peter \& Relly, Ben (eds) Demokrasi dan Konflik Yang Mengakar: Sejumlah Pilihan untuk Negosiator. International IDEA
Singaraja: Lembaga Penelitian Undiksha.

Azra, Azyumardi (2003) "Kerusuhan Massal di Indonesia Baru-Baru ini: Kemunduran Nasionalisme dan Kemunculan Separatisme", dalam INIS (ed) . Konflik Komunal di Indonesia Saat ini. Seri INIS:41. Leiden-Jakarta 2003

Bawa Atmadja, Nengah. (2008). Memudarnya Demokrasi Desa: Pengelolaan Tanah Adat, Konversi dan Implikasi Sosial dan Politik di Desa Adat Julah, Buleleng, Bali. (laporan penelitian). Singaraja: Lembaga Penelitian Undiksha.

Bawa Atmadja, Nengah. (2009). Pemberdayaan Desa Adat: Tantangan dan Hambatannya, Makalah disajikan pada seminar yang diselenggarakan oleh Universitas Pendidikan Nasional, Denpasar.

Bawa Atmadja, Nengah. (2006). Manajemen Konflik pada Masyarakat Desa Adat Multi Etnik di Kabupaten Buleleng, Bali, IKIP Negeri Singaraja

Belo, J. (1980). A Study on Customs Pertaining to Twins in Bali. New York: Columbia University Press.

Berger P. L, (1997). Religion And Globalization. London-New Delhi: Soge Publications Capra, Fritjof (2002) Titik Balik Peradaban. : Sains, Masyarakat dan Kebangkitan Kebudayaan. (edisi terjemahan). Jogjakarta: Bentang Budaya

Cavallaro, Dani (2001) Critical and Cultural Theory. Thematic 
Variations (edisi terjemahan). Jogjakarta: Futuh Frintika.

Fakih, Mansoer ( 2002) Runtuhnya Teori Pembangunan dan Globalisasi. Yogjakarta: INSIST Press dan Pustaka Pelajar
Fukuyama, Francis (2003) The End of History. Edisi Terjemahan. Yogjakarta. IRCISoD

Giddens. A and David H. (982). Classes, Power and Conflict: Classical and Contemporary, Ali Mandan penyunting, Debate, Polity Press. 